\title{
Influence of Flower Thrips on Fusarium Hardlock Severity
}

D. J. Mailhot, North Florida Research and Education Center, University of Florida, IFAS, Quincy 32351; J. J. Marois, Plant Pathology Department, North Florida Research and Education Center, University of Florida, IFAS, Quincy 32351; and D. L. Wright, Agronomy Department, North Florida Research and Education Center, University of Florida, IFAS, Quincy 32351

\begin{abstract}
Mailhot, D. J., Marois, J. J., and Wright, D. L. 2007. Influence of flower thrips on Fusarium hardlock severity. Plant Dis. 91:1423-1429.

Cotton (Gossypium hirsutum) fiber is sometimes affected by hardlock, which is characterized by a failure of the fiber to expand outward from the boll at maturity. Because affected fiber is inaccessible to mechanical harvesters, yield loss can be considerable. Hardlock has been linked to infection by Fusarium verticillioides. The involvement of flower thrips (Frankliniella spp.), which are commonly found in cotton flowers, was explored. At $1100 \mathrm{~h}$, approximately $10 \%$ of cotton flowers contained thrips that were carrying $F$. verticillioides. The effect of thrips and/or Fusarium in flowers and bolls was explored under greenhouse conditions. Exposing flowers to Fusarium and thrips resulted in bolls with the most severe symptoms. Exposure to either Fusarium or thrips alone resulted in more hardlock than was noted in the control group. The impact of thrips was also evaluated under field conditions. Field plots were treated with insecticides, a fungicide, both, or left untreated. Insecticides reduced thrips numbers and reduced hardlock severity. The fungicide had no impact on thrips numbers and was less effective at reducing hardlock. Combining insecticide and fungicide applications was no more effective than using insecticides alone, although it more frequently increased yield. The untreated control plots generally had the most severe hardlock and lowest yields. Reducing hardlock severity resulted in higher yields, although not consistently. These studies suggest that thrips increase the severity of hardlock, and reducing their numbers may diminish hardlock severity.
\end{abstract}

Hardlock is expressed as a failure of cotton (Gossypium hirsutum) fibers to expand outward (fluff out) after boll opening. Instead, they remain in compressed locules, which may have a faint pink or orange color. These compressed locules are frequently missed or knocked to the ground by mechanical harvesters. The resulting yield loss often ranges from 20 to $60 \%$, depending on the year. The fiber quality of affected locules is similar to that of healthy ones. Although it has not been formally recognized as a disease, it could be considered a subset of the boll rot complex. Hardlock is most severe along the gulf coast, possibly due to the region's high temperatures and humidity. Factors that contribute to development of boll rots also increase hardlock. These include prolonged periods of high humidity and large or dense plant canopies, and low, wet areas of fields with high organic matter (6). Attempts have been made to avoid harvest problems by the use of ultra-narrow row plantings and harvesting using a stripper,

Corresponding author: D. J. Mailhot

E-mail: dmailhot@ufl.edu

Accepted for publication 6 June 2007.

doi:10.1094/PDIS-91-11-1423

(C) 2007 The American Phytopathological Society but this has not proven feasible due to higher production costs and lower fiber quality (31).

In preliminary research, hardlock was associated with Fusarium verticillioides (15). Earlier publications typically used the name $F$. moniliforme, but this has been dropped in favor of the taxon $F$. verticillioides, since $F$. moniliforme was used too broadly and $F$. verticillioides was the older name (27). F. verticillioides commonly occurs in cotton fields and can be found growing saprophytically on crop residue. It has been isolated from both seeds and peduncles, and is sometimes found on mature cotton fiber in the field. It is hypothesized that $F$. verticillioides infects via the flowers and colonizes the developing boll. Inoculation of flowers with a conidial suspension of Fusarium resulted in more hardlock $(15,16)$.

Fusarium is strongly associated with boll rots in cotton, and the symptoms of hardlock are often included in descriptions of boll rots. Arndt (2) reported severe boll rots in South Carolina in 1950 and described a symptom called the "tight-lock condition". The prevalence of "tight-lock" ranged from 1 to $90 \%$ and was more severe near the coast. Bagga (4) reported that $F$. moniliforme occurred on 9 to $13 \%$ of boll rot samples. Fungal pathogens, including Fusarium, can be found within cotton bolls during the first several weeks of de- velopment (24). When inoculated directly into the pericarp of a developing boll, $F$. moniliforme causes disease on both adjacent carpels as well as the locule (28). Boll rot caused by inoculating flowers with Glomerella gossypii and Bacterium malvacearum was demonstrated as early as 1912 (10). The incidence of boll rot is higher with a closed canopy, due to increased humidity, although this is sometimes alleviated by a lack of rainfall. Reduced nitrogen fertilizer rates sometimes resulted in less boll rot, although canopy characteristics were not affected (25). Sanders and Snow (26) determined that boll rot was also influenced by the quantity of airborne inoculum of boll-rotting fungi, including Fusarium spp. At two locations in Louisiana, spore numbers peaked approximately 50 days after first bloom, and the first infected bolls were observed at 60 days. Spore concentrations were considerably reduced 10 to $100 \mathrm{~m}$ from cotton plants, so it is likely spores were originating in the crop. Spore concentration also varied considerably during the day, with the highest levels between 1800 and 0600 h. Among boll-rotting fungi, Fusarium spp. spores were second only to Diplodia gossypina in numbers. No relationship was found linking temperature, humidity, or rainfall to spore numbers. It was suggested the increasing levels of spores could have been generated by fungal growth on naturally shed flowers, bolls, squares, and leaves (26). In the case of boll rot caused by $\mathrm{Col}$ letotrichum capsici, damage to lint can vary from a "tight-locked" condition to severe degradation of fiber (23). Susceptibility to boll rot is also influenced by gossypol (a polyphenol in the Malvaceae), which can be increased by mechanical damage of the plant (7).

In North Florida, cotton flowers usually open between 0900 and $0930 \mathrm{~h}$ and are rapidly colonized by flower thrips. Frankliniella tritici (eastern flower thrips) are most common, but $F$. occidentalis (western flower thrips) and $F$. bispinosa (Florida flower thrips) are also present (14). Their numbers increase as the day progresses, and most flowers eventually contain 10 to 40 thrips (personal observation). Predatory insects such as Orius insidiosus (minute pirate bug) can reduce thrips numbers (21) but can sometimes be harmed by insecticide applications used to control thrips (29). Acephate is highly toxic to F. tritici 
(22). Spinosad is less toxic to F. tritici but nontoxic to $O$. insidiosus (28).

Thrips also commonly feed on the buds of cotton seedlings, resulting in leaf distortion. On mature cotton plants, they are not considered to be a problem, and in dry climates they are considered a beneficial predator of spider mites. They are not known to be affected by the Bt (Bacillus thuringiensis) toxin and are controlled on seedling cotton with insecticides.

Thrips possess only one mandible, which is used for cutting into plant tissue, and a stylet through which food is drawn. This results in open wounds to the plant, which could allow easier penetration of the tissue by germinating Fusarium conidia. Females of Frankliniella occidentalis feed more frequently and intensely than males, resulting in more tissue damage (30). Farrar and Davis (11) investigated the relationship between $F$. occidentalis and Fusarium ear rot of corn. They concluded that thrips may be acting as vectors of Fusarium verticillioides or as wounding agents by feeding on the plant tissue. Pickett et al. (20) reported that $68 \%$ of adult Frankliniella occidentalis found on cotton plants occurred on fruiting structures, with most of these occurring in the flower itself. This is consistent with the concept that cotton pollen may be preferable to leaves as a food source for thrips (1).

Proceeding from the assumption that $F$. verticillioides infects flowers on the day of bloom, we hypothesize that flower thrips may increase the likelihood of fungal infection. This could be due to vectoring inoculum into the flower as they arrive in the morning or the mechanical damage they cause in the process of feeding that may allow the pathogen to invade more easily. In order to demonstrate the association of thrips with Fusarium hardlock, a series of studies was performed. The objectives of the research were to determine the prevalence of thrips exposed to Fusarium in the field, whether artificially exposed thrips would cause hardlock in a controlled setting, and if field applications of insecticide would reduce hardlock.

\section{MATERIALS AND METHODS}

Fusarium isolation from flowers. White cotton flowers were collected from a crop rotation study in Quincy, FL. In 2004, cultivar DPL 458 BG/RR, which produces the Bacillus thuringiensis endotoxin and provides resistance to glyphosate herbicide, was planted. In 2005, cultivar DPL 555 BG/RR, which provided the same benefits, was used. The plants were maintained according to recommendations of the University of Florida extension service, and treated with Karate (lambda cyhalothrin) when necessary to control aphids, leafhoppers, and grasshoppers. Fungicides were not applied during the growing season. Flowers were collected between 1000 and $1100 \mathrm{~h}$, placed in individual plastic bags, and sealed shut to contain any thrips present. The samples were then refrigerated for approximately 3 $\mathrm{h}$ to reduce thrips mobility. All thrips from a flower were then placed onto a petri dish of one-quarter-strength acidified potato dextrose agar (APDA). The dish was then covered and sealed with Parafilm to prevent any thrips from escaping. The thrips were permitted to move around the dish, allowing any spores on them to be spread across the plate. This procedure was performed for each flower sampled. In 2005, the procedure was modified. All thrips were collected from a flower in the field using an aspirator, placed directly onto an APDA petri dish, and sealed with Parafilm. The thrips survived for approximately 3 days, after which fungal colonies were counted, and suspected Fusarium colonies were marked. After 7 to 10 days, suspected Fusarium colonies were re-examined to verify the original count. This method was chosen since the small body mass of the thrips would not be conducive to grinding and applying to the media. Between 20 and 100 flowers were sampled on each date, depending on the number of thrips present and weather conditions. The number of thrips and Fusarium colonies isolated per flower were analyzed using the SAS general linear model, and means were separated using Tukey's test. This study was designed to provide insight on whether transport of Fusarium by thrips occurred on a scale similar to the severity of hardlock observed in the field. The isolations were initially conducted using all thrips from a flower instead of individual thrips since this would allow a comparison of the proportion of flowers with Fusarium to the proportion of hardlocked locules, and this procedure was continued due to the low isolation rates and variability between days.

Greenhouse studies. Cotton was planted and maintained in a greenhouse at the North Florida Research and Education Center in Quincy, FL. The temperature was typically between 25 and $35^{\circ} \mathrm{C}$, but occasionally reached $45^{\circ} \mathrm{C}$. The potting mix consisted of peat moss and composted bark, and plants were watered as necessary. After germination, each potted seedling was treated with $0.17 \mathrm{ml}$ of Admire (imidacloprid) to prevent insect infestations. Approximately $5 \mathrm{~g}$ of water-soluble 15-30-15 fertilizer was applied to each plant early in the experiment. Pix (mepiquat chloride) was applied at a rate of 0.01 $\mathrm{ml}$ per plant on one or two occasions to reduce plant growth. Excessive height and boll weight required some plants to be attached to bamboo stakes to remain upright. Shortly before flowering, plants were divided into four groups: 1, control; 2, thrips-only; 3, thrips exposed to Fusarium; and 4, Fusarium-inoculated. The thripsonly treatment consisted of the placement of 10 thrips into each open flower. F. verti- cillioides isolates from infected bolls in 2001 were transferred to one-quarterstrength APDA. These isolates resulted in hardlock when inoculated into flowers $(16,17)$. One transfer from each of the three isolates was used to produce a mixed culture to better approximate inoculum present in the field. After 10 to 14 days, conidia were rinsed from the culture using deionized water, creating a suspension of 9 to $33 \times 10^{5}$ conidia per $\mathrm{ml}$. These suspensions remained viable for 3 days when refrigerated. Thrips were exposed to inoculum by placing them on a PDA culture of $F$. verticillioides for approximately $1 \mathrm{~h}$. Ten of these thrips were then transferred into each available flower within the appropriate treatment. Unlike flowers produced in a field setting, the petals in the greenhouse expanded further, yielding a more open flower. Treatments were spatially separated to prevent thrips migration. In 2003, thrips and nonthrips treatments were separated by approximately $8 \mathrm{~m}$ with a 3-m-high barrier between them. The experiment was continued until thrips were detected in the nonthrips treatments. In 2005, thrips and nonthrips treatments were placed in separate rooms of the greenhouse (with identical temperature settings). No thrips movement was observed, and the experiment continued until flowering ceased. Flowers were tagged with ribbons to indicate the treatment and date. After all bolls on a plant were open, they were evaluated for hardlock. Locules displaying the characteristic failure of fiber to expand were deemed to be affected. The numbers of affected and total locules for each boll were recorded.

The first study was conducted from January to May of 2003 using cultivar DPL $555 \mathrm{BG} / \mathrm{RR}$. Flowering occurred from March to April, and 15 plants were used in each of the four treatments. F. occidentalis was raised on green beans in cages. $F$. occidentalis was locally common prior to 2003 and was frequently observed in flowers. In the Fusarium inoculation treatment, approximately $5 \mathrm{ml}$ of a conidial suspension was sprayed into each open flower. In the second study, flowering occurred from April to May 2005. In that study, approximately $1 \mathrm{ml}$ of the conidial suspension of F. verticillioides was delivered with a syringe onto the stigma. Exposure to water results in lysing of cotton pollen, reducing the chance of successful pollination (9). This modification reduced the flower abortion rate and was maintained in subsequent studies. In this trial, insufficient thrips were available, resulting in too few treated bolls to evaluate the thrips treatments. In the third study, the cotton flowered from July to August, and wild-captured Frankliniella tritici was used to more accurately simulate field conditions. This study was replicated from October to November 2005. Thrips were captured from the same plot as the Fusarium-isolation study de- 
scribed previously. At the time of capture, they were briefly exposed to water, with the goal of dislodging any spores present, and sometimes kept in captivity for several days using tomatillo (Physalis ixocarpa) fruit as a food source. In this third study, a second cotton cultivar, DPL 444 BG/RR, was added and eight plants per cultivar were used in each of the four treatments. The DPL 444 plants required one to two extra applications of mepiquat chloride to keep them similar in height to DPL 555. DPL 444 also continued flowering for 4 to 5 weeks longer than DPL 555. The first and second studies were analyzed separately by treatment, each with a single replication, using the SAS general linear model. Means were separated using Tukey's test. The third study included two replications separated by time.

Field studies. Two field studies, approximately $65 \mathrm{~km}$ apart, were conducted at branches of the North Florida Research and Education Center in Quincy and Marianna. The impact of these studies on thrips population dynamics was described by Mailhot et al. (14). Cultivar DPL 555 $\mathrm{Bt} / \mathrm{RR}$ was maintained according to the recommendations of the University of Florida extension service unless otherwise noted. Acephate and lambda cyhalothrin were used when needed to control the southern green stink bug (Nezara viridula) and the brown stink bug (Euschistus ser$v u s$ ). Hardlock severity was assessed approximately 2 weeks after defoliation. The

Table 1. Mean numbers of thrips and Fusarium CFU per cotton flower in Quincy, FL

\begin{tabular}{cccc}
\hline Year & Thrips & Fusarium & No. flowers \\
\hline 2003 & $4.80 \mathrm{a}^{\mathrm{z}}$ & $0.07 \mathrm{a}$ & 329 \\
2004 & $2.35 \mathrm{~b}$ & $0.13 \mathrm{a}$ & 23 \\
2005 & $3.54 \mathrm{ab}$ & $0.07 \mathrm{a}$ & 273 \\
\hline
\end{tabular}

${ }^{\mathrm{z}}$ Numbers followed by the same letter are not significantly different according to Tukey's test $(P \leq 0.05)$. The number of Fusarium isolations varied by day, with several days randomly scattered throughout the season contributing to most of the isolations for the season (data not shown). numbers of hardlocked and total locules per boll were recorded on five plants selected at random in each plot. This provided data from approximately 100 to 120 locules per plot. Yield was obtained by harvesting two rows with a spindle plot picker. The data were analyzed by year, treatment, and block (not significant, not shown) using the SAS general linear model, and means were separated using Tukey's test.

In Quincy, a large, pre-existing fungicide-insecticide study was utilized to evaluate thrips, hardlock, and yield for 2 years. Treatments were arranged in a randomized complete block design with four replications. There were 28 treatments in 2004 and 10 treatments in 2005. Plots were six rows ( $0.9 \mathrm{~m}$ between rows) by $9 \mathrm{~m}$ long. Control and insecticide-treated plots (with or without fungicide, depending on the year) were sampled for thrips. Other treatments included varied rates and timings of fungicide applications but were not sampled. In 2004, the insecticide treatment consisted of weekly applications of 0.10 $\mathrm{kg}$ a.i./ha of spinosad on Mondays and $0.56 \mathrm{~kg} / \mathrm{ha}$ acephate $+0.04 \mathrm{~kg}$ a.i./ha lambda cyhalothrin on Thursdays. In 2005, $0.02 \mathrm{~kg}$ a.i./ha lambda cyhalothrin was used, and $0.9 \mathrm{~kg} / \mathrm{ha}$ of thiophanate-methyl was applied every 2 weeks. In each of the eight plots, 12 flowers were collected weekly and stored for insect identification. The two center rows of each plot were reserved for hardlock and yield data, and thrips were sampled from the second and fifth rows of each plot.

At the Marianna site, the effects of insecticides and fungicides on thrips, hardlock, and yield were studied for 3 years. The site was part of a Paspalum notatum (bahiagrass) rotation, which consisted of 2 years of bahiagrass, 1 year of peanut, and 1 year of cotton. The plots were eight rows in width, with $0.9 \mathrm{~m}$ between rows, and 18 $\mathrm{m}$ in length. Rows were oriented north to south. At each end, a 6-m-wide section of peanuts was planted. Because peanuts support large numbers of Frankliniella fusca and are often planted in proximity to cotton, it was suspected they could influence populations of thrips in nearby cotton flowers. However, no influence of peanut on thrips in cotton was detected, and the data are not reported. A randomized complete block design was used with four blocks and four treatments. The experiment included untreated control plots and three other treatments which were applied during the bloom period. The insecticide treatment consisted of spinosad at $0.07 \mathrm{~kg}$ a.i./ha alternated weekly with acephate at $0.9 \mathrm{~kg}$ a.i./ha. The fungicide treatment consisted of thiophanate-methyl at $1.1 \mathrm{~kg}$ a.i./ha applied weekly. A fourth treatment included a weekly application of both the insecticide and fungicide sprays listed above. In 2003, difficulties were encountered when applying fertilizer. To ensure that correctly fertilized rows were available for harvest, thrips were sampled from the two outer rows of each plot, while hardlock and yield data were obtained from two of the inner rows. Sampling of the outer rows was repeated in subsequent years for consistency. Eight flowers were sampled weekly from each plot and stored until thrips could be counted.

\section{RESULTS}

Fusarium isolation. Flowers sampled contained up to 30 thrips, although two to five was more typical. The mean number of Fusarium colonies that originated from thrips varied from 0.07 to 0.13 per flower (Table 1). Significant differences were present by year for thrips numbers, but not Fusarium colonies.

Greenhouse studies. In 2003, the addition of thrips (Frankliniella occidentalis) previously exposed to $F$. verticillioides to flowers resulted in significantly more hardlock relative to the untreated control group (Table 2). Inoculating flowers with an $F$. verticillioides conidial suspension also significantly increased hardlock. Adding thrips to flowers in the absence of Fusarium did not result in significant differences compared with the control group.

In the third study, the results differed slightly by cultivar. On the cultivar DPL

Table 2. Effect of exposing flowers to thrips and Fusarium on hardlock under greenhouse conditions

\begin{tabular}{|c|c|c|c|c|c|c|c|}
\hline & & \multirow{2}{*}{\multicolumn{2}{|c|}{$\begin{array}{c}2003 \\
\text { March-April }\end{array}$}} & \multicolumn{4}{|c|}{2005} \\
\hline & & & & \multicolumn{2}{|c|}{ April-May } & \multicolumn{2}{|c|}{ Jul-Aug Oct-Nov } \\
\hline & & $\begin{array}{c}\text { Percent } \\
\text { hardlock }\end{array}$ & $\begin{array}{l}\text { No. } \\
\text { bolls }\end{array}$ & $\begin{array}{c}\text { Percent } \\
\text { hardlock }\end{array}$ & $\begin{array}{l}\text { No. } \\
\text { bolls }\end{array}$ & $\begin{array}{c}\text { Percent } \\
\text { hardlock }\end{array}$ & $\begin{array}{l}\text { No. } \\
\text { bolls }\end{array}$ \\
\hline DP 444 & $\begin{array}{l}\text { Fusarium + thrips } \\
\text { Fusarium } \\
\text { Thrips } \\
\text { Control }\end{array}$ & $\begin{array}{l}\cdots \\
\cdots \\
\cdots \\
\cdots\end{array}$ & $\begin{array}{l}\cdots \\
\cdots \\
\cdots \\
\cdots\end{array}$ & $\begin{array}{l}\cdots \\
\cdots \\
\cdots \\
\cdots\end{array}$ & $\begin{array}{l}\cdots \\
\cdots \\
\cdots \\
\cdots\end{array}$ & $\begin{array}{l}37 \mathrm{ab}^{\mathrm{y}} \\
44 \mathrm{a} \\
45 \mathrm{a} \\
27 \mathrm{~b}\end{array}$ & $\begin{array}{l}37 \\
51 \\
58 \\
41\end{array}$ \\
\hline DP 555 & $\begin{array}{l}\text { Fusarium }+ \text { thrips }^{\mathrm{z}} \\
\text { Fusarium } \\
\text { Thrips }^{\mathrm{z}} \\
\text { Control }\end{array}$ & $\begin{array}{l}66 \mathrm{a} \\
56 \mathrm{ab} \\
39 \mathrm{bc} \\
32 \mathrm{c}\end{array}$ & $\begin{array}{l}25 \\
58 \\
36 \\
50\end{array}$ & $\begin{array}{c}\ldots \\
20 \mathrm{a} \\
\ldots \\
12 \mathrm{a}\end{array}$ & $\begin{array}{l}\ldots \\
30 \\
\ldots \\
67\end{array}$ & $\begin{array}{l}57 \mathrm{a} \\
37 \mathrm{~b} \\
40 \mathrm{~b} \\
23 \mathrm{c}\end{array}$ & $\begin{array}{l}26 \\
80 \\
85 \\
76\end{array}$ \\
\hline
\end{tabular}

${ }^{y}$ Numbers in a column within a cultivar followed by the same letter are not significantly different according to Tukey's test $(P \leq 0.05)$. In the second study (April to May 2005), the Fusarium-inoculated and control groups only differed at the $P=0.10$ level of significance.

${ }^{z}$ Thrips added in 2003 were Frankliniella occidentalis, while those in 2005 were $F$. tritici. 
555, Fusarium-exposed thrips (F. tritici) resulted in the highest rates of hardlock. Both $F$. verticillioides and thrips individually increased hardlock compared with the control treatment. On the cultivar DPL 444, Fusarium-exposed thrips did not increase the incidence of hardlock relative to the control.

Fewer bolls successfully reached maturity when they were exposed to Fusariumcarrying thrips (Table 2). On several days, flowers were not treated and the resulting bolls were not included in the experiment. However, the bolls that formed from those untreated flowers rarely aborted.

Field studies. In Quincy, the use of insecticides alone (2004) or paired with a fungicide (2005) significantly reduced thrips numbers (Table 3) by $84 \%$ in 2004 and $92 \%$ in 2005 . The incidence of hardlock was not affected in 2004, but in 2005 the incidence of hardlock was significantly reduced from 32 to $18 \%$ with the insecticide. Yield was not significantly affected in either year.

In Marianna, insecticides significantly reduced numbers of thrips in all years (Table 4), while fungicide applications had no impact. Insecticides significantly reduced hardlock in all years approximately 30 to $50 \%$. Fungicide applications provided significant reductions in hardlock for some years, but not all. Combining applications of the insecticides and fungicides did not provide additional reductions in hardlock in any year. Yields were low in 2003, and spraying was not beneficial. Yields were higher in 2004, but only the combined sprays resulted in a significant improvement. In 2005, overall yields were higher than in previous years, and insecticide applications significantly increased yields.

The relationship between thrips numbers and hardlock incidence in Marianna, FL, is illustrated in Figure 1. The mean number of thrips per flower during the entire season is compared with hardlock severity for each plot. Values from 2 of the 48 plots were excluded from these regressions as outliers. A positive association of flower thrips and hardlock was observed in 2003 $\left(r^{2}=0.28, P=0.04\right)$ and $2005\left(r^{2}=0.34, P\right.$ $=0.02$ ). In 2004, no relationship was apparent. When plots were examined across all 3 years, the pattern is clearer (Fig. 2). The $r^{2}$ values range from 0.53 to 0.77 and were highly significant. Combining plots from all treatments and years resulted in the same trend $\left(r^{2}=0.60, P<0.0001\right)$ (Fig. 3).

Although there were no significant treatment differences in hardlock severity in Quincy in 2004 (Table 3), regressions showed the same trend observed in Marianna (Figs. 4 to 6). In addition, none of the 16 plots were outliers. The association was stronger in $2004\left(r^{2}=0.63, P=\right.$ $0.02)$ than in $2005\left(r^{2}=0.39, P=0.10\right)$ (Fig. 4). Grouping plots by treatment showed similar results (Fig. 5). Grouping all plots confirmed the pattern observed in Marianna $\left(r^{2}=0.25, P=0.05\right)($ Fig. 6$)$.

\section{DISCUSSION}

These results suggest thrips are involved in the incidence of cotton hardlock symptoms observed in the field, probably as vectors of the $F$. verticillioides or by damaging flower tissues and creating an infection court. In greenhouse studies, the pres-

Table 3. Effect of fungicide and insecticide treatments on thrips, hardlock, and yield in Quincy, FL

\begin{tabular}{|c|c|c|c|c|c|c|}
\hline \multirow[b]{2}{*}{ Treatment } & \multicolumn{2}{|c|}{ Thrips/flower } & \multicolumn{2}{|c|}{ Hardlock } & \multicolumn{2}{|c|}{ Yield (kg lint/ha) } \\
\hline & 2004 & 2005 & 2004 & 2005 & 2004 & 2005 \\
\hline Contro & $6.10 \mathrm{a}^{\mathrm{x}}$ & $4.18 \mathrm{a}$ & $0.48 \mathrm{a}$ & $0.32 \mathrm{a}$ & $1,221 \mathrm{a}$ & $1,380 \mathrm{a}$ \\
\hline Insecticide + fungicide ${ }^{y}$ & & $0.32 \mathrm{~b}$ & $0.42 \mathrm{a}$ & $0.18 \mathrm{~b}$ & $1,365 \mathrm{a}$ & $1,419 \mathrm{a}$ \\
\hline Insecticide $^{z}$ & $0.95 \mathrm{~b}$ & $\ldots$ & $0.42 \mathrm{a}$ & $\ldots$ & $1,142 \mathrm{a}$ & $\ldots$ \\
\hline
\end{tabular}

${ }^{\mathrm{w}}$ Untreated.

${ }^{\mathrm{x}}$ Numbers followed by the same letter are not significantly different according to Tukey's test $(P \leq$ $0.05)$.

y $0.1 \mathrm{~kg} / \mathrm{ha}$ of spinosad on Mondays, $0.56 \mathrm{~kg} / \mathrm{ha}$ acephate $+0.02 \mathrm{~kg} / \mathrm{ha}$ lambda cyhalothrin on Thursdays, and $0.9 \mathrm{~kg} / \mathrm{ha}$ of thiophanate methyl every 2 weeks.

${ }^{\mathrm{z}} 0.1 \mathrm{~kg} / \mathrm{ha}$ of spinosad on Mondays and $0.56 \mathrm{~kg} / \mathrm{ha}$ acephate $+0.04 \mathrm{~kg} / \mathrm{ha}$ lambda cyhalothrin on Thursdays.

ence of both thrips and Fusarium in a flower resulted in more hardlock than the presence of thrips or Fusarium alone. The field studies indicated that both thrips numbers and hardlock severity could be reduced by insecticide applications. This link was further strengthened by the correlation between thrips numbers and hardlock in all years of the study.
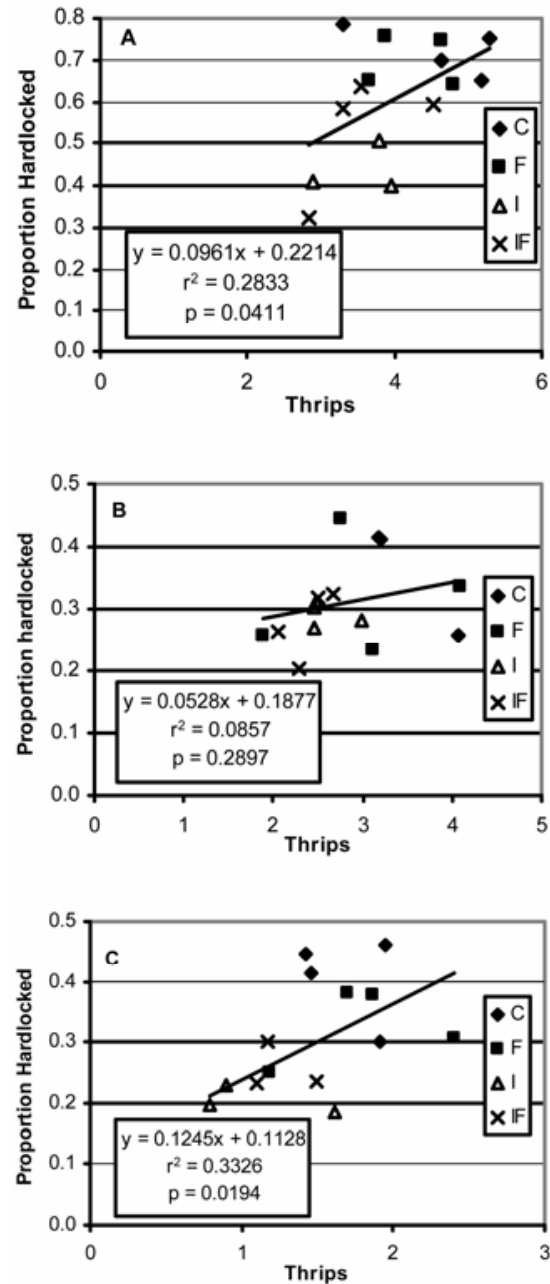

Fig. 1. Relationship between mean thrips numbers and hardlock incidence per plot in Marianna, FL in A, 2003; B, 2004; C, 2005. Treatment $\mathrm{C}=$ untreated control, $\mathrm{F}=$ fungicide $(1.1 \mathrm{~kg} / \mathrm{ha}$ thiophanate methyl weekly), $\mathrm{I}=$ insecticide $(0.07 \mathrm{~kg} / \mathrm{ha}$ spinosad or $0.9 \mathrm{~kg} / \mathrm{ha}$ acephate alternated weekly), and IF = both insecticide and fungicide treatments listed previously.

Table 4. Effect of fungicide and insecticide treatments on thrips per flower, hardlock, and yield in Marianna, FL

\begin{tabular}{|c|c|c|c|c|c|c|c|c|c|}
\hline \multirow[b]{2}{*}{ Treatment } & \multicolumn{3}{|c|}{ Thrips } & \multicolumn{3}{|c|}{ Hardlock } & \multicolumn{3}{|c|}{ Yield (kg lint/ha) } \\
\hline & 2003 & 2004 & 2005 & 2003 & 2004 & 2005 & 2003 & 2004 & 2005 \\
\hline Control $^{\mathrm{v}}$ & $4.1 \mathrm{a}^{\mathrm{w}}$ & $3.3 \mathrm{a}$ & $1.7 \mathrm{a}$ & $0.72 \mathrm{a}$ & $0.41 \mathrm{a}$ & $0.41 \mathrm{a}$ & $471 \mathrm{ab}$ & $813 \mathrm{~b}$ & $1,138 \mathrm{~b}$ \\
\hline Fungicide $^{\mathrm{x}}$ & $3.8 \mathrm{ab}$ & $3.0 \mathrm{ab}$ & $1.8 \mathrm{a}$ & $0.69 \mathrm{a}$ & $0.31 \mathrm{~b}$ & $0.33 \mathrm{~b}$ & $476 \mathrm{a}$ & $895 \mathrm{ab}$ & $1,104 \mathrm{~b}$ \\
\hline Insecticide + fung. ${ }^{y}$ & $3.1 \mathrm{bc}$ & $2.4 \mathrm{~b}$ & $1.2 \mathrm{~b}$ & $0.52 \mathrm{~b}$ & $0.28 \mathrm{~b}$ & $0.23 \mathrm{c}$ & $372 \mathrm{~b}$ & $1,051 \mathrm{a}$ & $1,506 \mathrm{a}$ \\
\hline Insecticide $^{\mathrm{z}}$ & $2.8 \mathrm{c}$ & $2.6 \mathrm{~b}$ & $1.1 \mathrm{~b}$ & $0.47 \mathrm{~b}$ & $0.29 \mathrm{~b}$ & $0.19 \mathrm{c}$ & $445 \mathrm{ab}$ & $990 \mathrm{ab}$ & $1,429 \mathrm{a}$ \\
\hline
\end{tabular}

${ }^{\mathrm{v}}$ Untreated.

${ }^{w}$ Numbers followed by the same letter in a column are not significantly different according to Tukey's test $(P \leq 0.05)$.

$\times 1.1 \mathrm{~kg} / \mathrm{ha}$ thiophanate methyl weekly.

y $0.07 \mathrm{~kg} / \mathrm{ha}$ spinosad or $0.9 \mathrm{~kg} / \mathrm{ha}$ acephate alternated weekly combined with fungicide treatment listed previously.

${ }^{z} 0.07 \mathrm{~kg} / \mathrm{ha}$ spinosad or $0.9 \mathrm{~kg} / \mathrm{ha}$ acephate alternated weekly. 
The incidence with which $F$. verticillioides was isolated from thrips in flowers was lower than commonly observed rates of hardlock in the field. Because the number of thrips per flower increases for most of the day, sampling in the afternoon could have resulted in isolation rates more similar to observed rates of hardlock. Although hardlock incidence declined from 2003 to 2005 , there was no change in the frequency with which Fusarium was isolated from thrips in the field. This suggests that yearly fluctuations in hardlock may not result exclusively from fluctuations in thrips populations, but may also be affected by other sources of inoculum. Sanders and Snow (26) found the number of airborne spores of Fusarium increased for several weeks after first bloom, possibly due to saprophytic growth on shed flowers and other tissue, before finally declining approximately 6 weeks later. That trend was not observed in this study, although more samples or direct measurements of airborne inoculum might have supported this observation. Ooka and Kommedahl (18) observed a similar situation with $F$. moniliforme spores in corn fields. Spore numbers were lowest while the plant was actively growing and increased as it reached maturity. They also observed wind-blown soil containing $F$. moniliforme spores that may have traveled 300 to 400 $\mathrm{km}$. However, Fernando et al. (12) found more airborne spores within $1.5 \mathrm{~m}$ of an

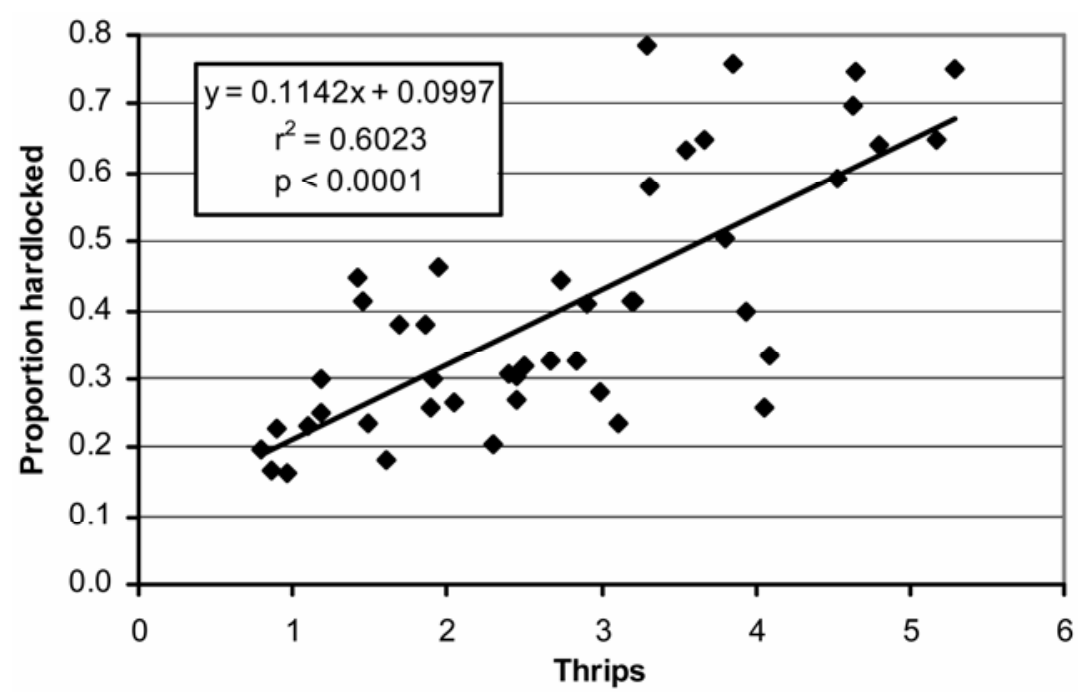

Fig. 3. Relationship between mean thrips numbers and hardlock incidence per plot in Marianna, FL for all treatments and years.
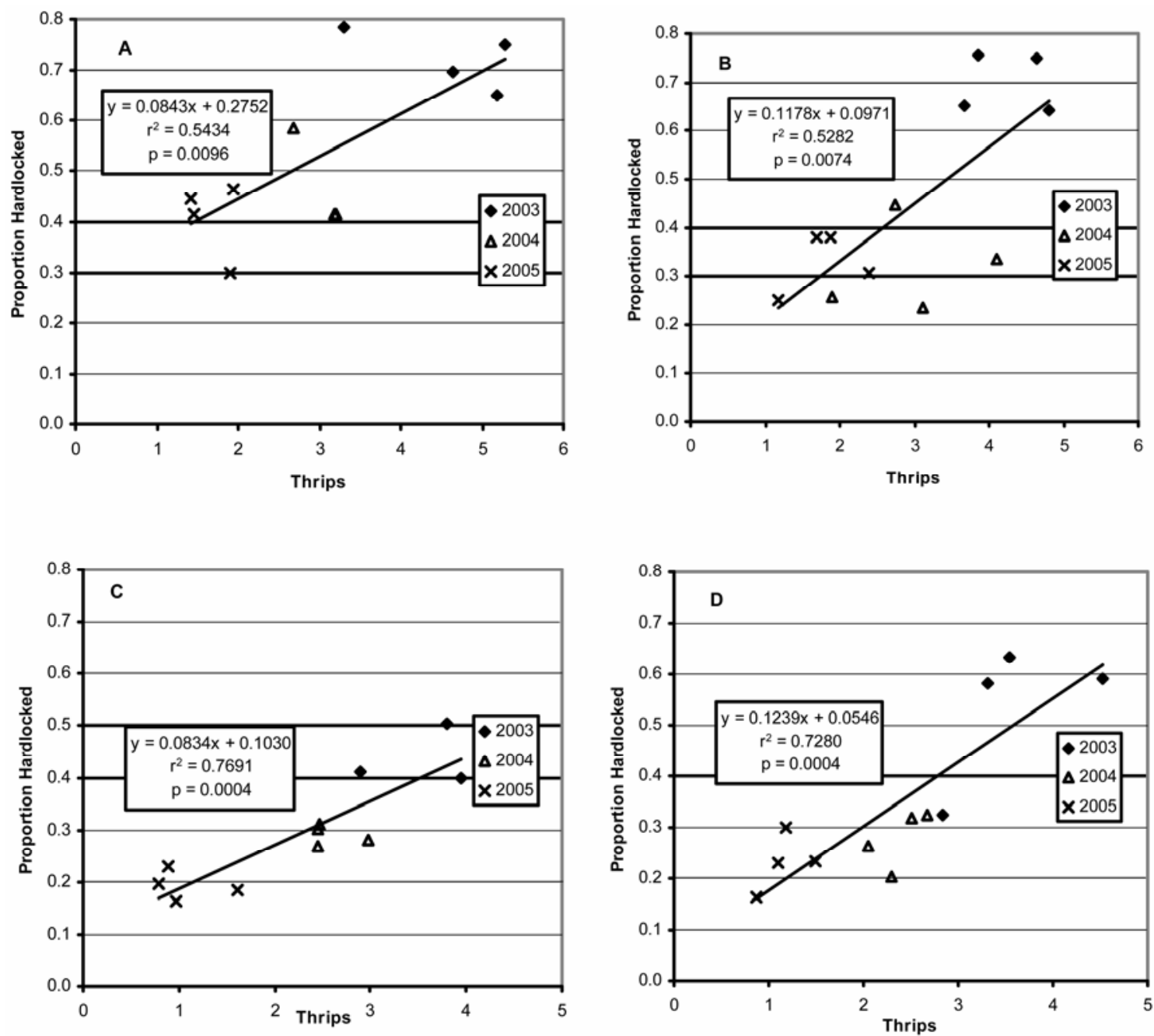

Fig. 2. Relationship between mean thrips numbers and hardlock incidence per plot in Marianna, FL for $\mathbf{A}$, untreated control; $\mathbf{B}$, fungicide (1.1 kg/ha thiophanate methyl weekly); $\mathbf{C}$, insecticide $(0.07 \mathrm{~kg} / \mathrm{ha}$ spinosad or $0.9 \mathrm{~kg} / \mathrm{ha}$ acephate alternated weekly); $\mathbf{D}$, insecticide + fungicide $(0.07 \mathrm{~kg} / \mathrm{ha}$ spinosad or 0.9 $\mathrm{kg} / \mathrm{ha}$ acephate alternated weekly $+0.07 \mathrm{~kg} / \mathrm{ha}$ thiophanate methyl). 
infected wheat field than at $5 \mathrm{~m}$, suggesting that local production of inoculum may be most important. Further studies comparing inoculum quantity on the day of bloom to hardlock in the resulting bolls would be necessary to adequately address this issue.

The thrips-Fusarium isolation study was undertaken with the assumption that thrips were either transporting inoculum into the cotton flowers or damaging flower tissues, thereby increasing the opportunity for infection by $F$. verticillioides. The results indicated that thrips are capable of transporting inoculum, which supports previous studies. Atakan and Ozgur (3) observed that thrips populations in red flowers were highest at $0530 \mathrm{~h}$, after which they began dispersing. Sanders and Snow (26) found the release of spores of bollrotting pathogens (including Fusarium spp.) to be highest between 1800 and 0600 h. Fernando et al. (12) found spore release of $F$. moniliforme to be highest in wheat fields between 1600 and $0800 \mathrm{~h}$. This allows a time period between 0530 and around $0930 \mathrm{~h}$ before thrips enter new flowers and during which they could come into contact with recently deposited spores from the previous night. This does not preclude the possibility that feeding damage by thrips allows more infections, and perhaps both pathways work synergistically.

It is not clear how common $F$. verticillioides is in cotton fields. Palmateer et al. (19) found $F$. moniliforme to be relatively uncommon among Fusarium species isolated from living cotton plant tissue. In contrast, Baird and Carling (5) found several Fusarium species to be present on 22 to $38 \%$ of dead cotton roots. Although $F$. verticillioides was not listed in the six most frequently isolated Fusarium species, five other unlisted species were isolated from 1 to $6 \%$ of samples. Bolkan et al. (8) demonstrated $F$. moniliforme conidia to be shortlived ( 6 to 13 weeks) in the soil in the absence of host tissues. However, incorporating stem and leaf tissue from pineapple into the soil increased survival to at least 12 months. It should be noted that cotton stems, roots, and fiber from the previous year are commonly found in cotton fields. This suggests cultural practices may influence the quantity of inoculum present.
In the greenhouse inoculation studies, hardlock symptoms occurred in the group of plants not challenged with thrips or $F$. verticillioides, although at lower rates than the experimental treatments. Flowers were observed closely for thrips to ensure $F$. verticillioides was not being transported to noninoculated flowers. In addition, the air entering this greenhouse passed through an evaporative cooler, reducing the opportunity for airborne inoculum from outdoors to reach the flowers. Hence, it appears a certain amount of observed hardlock may result from unknown factors. The first and third greenhouse studies also suggest that particular species of thrips may not be important in hardlock, since similar results were obtained with both $F$. occidentalis and $F$. tritici. It also demonstrated that cotton varieties do not respond identically to hardlock. However, the two varieties also showed large differences in response to growth regulators, flower production, and boll retention, so comparisons between them should not be extrapolated to field performance. It is also unclear why Fusarium-exposed thrips resulted in the highest
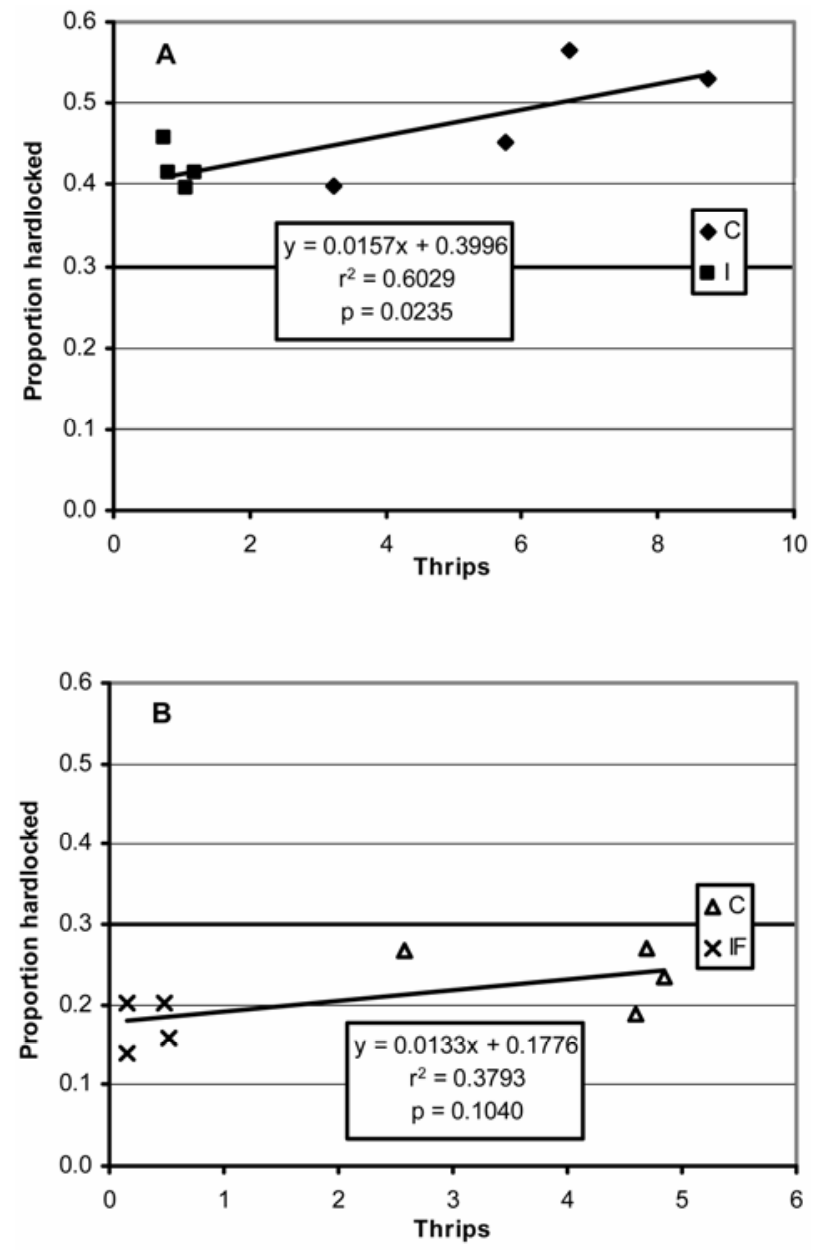

Fig. 4. Relationship between mean thrips numbers and hardlock incidence per plot in Quincy, FL in A, 2004; B, 2005. Treatment C = untreated control, I = insecticide $(0.1 \mathrm{~kg} / \mathrm{ha}$ of spinosad on Mondays and $0.56 \mathrm{~kg} / \mathrm{ha}$ acephate +0.04 $\mathrm{kg} / \mathrm{ha}$ lambda cyhalothrin on Thursdays), $\mathrm{IF}=$ insecticide + fungicide $(0.1$ $\mathrm{kg} / \mathrm{ha}$ of spinosad on Mondays, $0.56 \mathrm{~kg} / \mathrm{ha}$ acephate $+0.02 \mathrm{~kg} / \mathrm{ha}$ lambda cyhalothrin on Thursdays, and $0.9 \mathrm{~kg} / \mathrm{ha}$ of thiophanate methyl every 2 weeks).
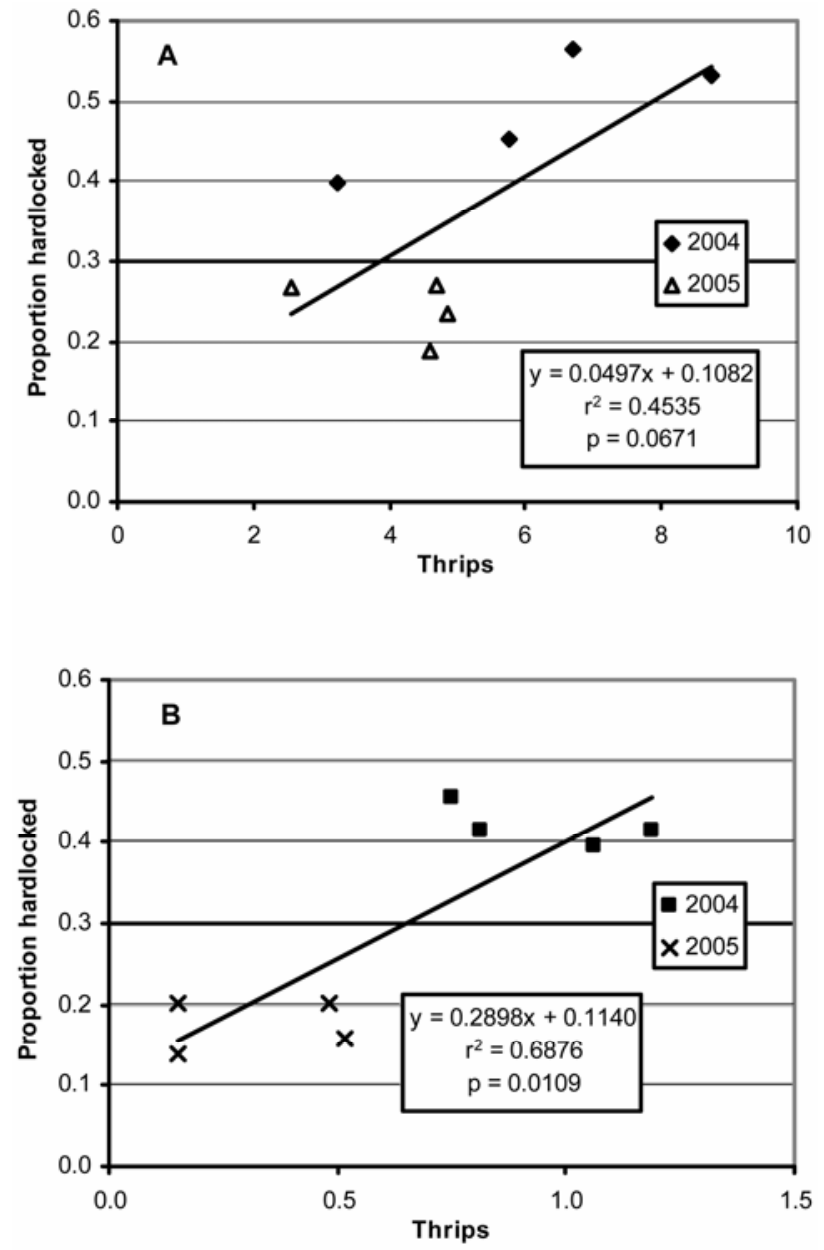

Fig. 5. Relationship between mean thrips numbers and hardlock incidence per plot in Quincy, FL for A, untreated control; $\mathbf{B}$, insecticide alone (2004) or with a fungicide (2005): insecticide $=0.1 \mathrm{~kg} / \mathrm{ha}$ of spinosad on Mondays and $0.56 \mathrm{~kg} / \mathrm{ha}$ acephate $+0.04 \mathrm{~kg} / \mathrm{ha}$ lambda cyhalothrin on Thursdays, fungicide $=0.9 \mathrm{~kg} / \mathrm{ha}$ of thiophanate methyl every 2 weeks. 
levels of hardlock in DP 555, but the incidence of hardlock in the treatment with both Fusarium and thrips was lower than exposure to either thrips or Fusarium alone in DP 444. The observation of increased abortion of bolls in the first 2 to 3 weeks of development may be related to the higher levels of gossypol observed at that stage in development (7). If hardlock symptoms were a result of shortages in photosynthates, the reduction in boll numbers might have alleviated some of the problem. Alternatively, the aborted bolls could represent a more severe or advanced category of infection, although this is unlikely since $F$. verticillioides could not be reisolated from aborted bolls.

Applications of insecticides to field plots effectively reduced populations of thrips in both locations of this study. This was not unexpected since the particular insecticides chosen to control thrips did not negatively affect Orius spp., which are natural predators of thrips (13). The relationship between numbers of thrips and incidence of hardlock was clear in the Marianna trial, but was only obvious in 1 of 2 years in Quincy. This suggests that while thrips are an important factor, they are not the only determinant of hardlock incidence. However, the greater percent reduction in thrips due to spraying in Marianna in 2005 compared with previous years coincided with a greater reduction in hardlock. Although reducing populations of thrips within a season reduced the incidence of hardlock, it was not clear whether declining thrips populations led to reduced hardlock, or if both were being influenced by a third factor. Yield can be adversely affected by many factors, and in some cases hardlock may not be a significant contributor to low yields. At the same time, reducing thrips numbers, regardless of their initial population, was usually benefi- cial, suggesting it may be a useful management strategy for controlling hardlock.

\section{ACKNOWLEDGMENTS}

We thank Brian Kidd, Pawel Wiatrak, and Wayne Branch for their assistance with these studies, and Cerexagri and Cotton Inc. for providing funding.

\section{LITERATURE CITED}

1. Agrawal, A. A., Kobayashi, C., and Thaler, J. S. 1999. Influence of prey availability and induced host-plant resistance on omnivory by western flower thrips. Ecology 80(2):518-523.

2. Arndt, C. H. 1950. Boll rots of cotton in South Carolina in 1949. Plant Dis. Rep. 34(6): 176.

3. Atakan, E., and Ozgur, A. F. 2001. Determining the favorable sampling time for Frankliniella intonsa on cotton. Pages 225-227 in: Thrips and Tospoviruses: Proc. Int. Sympos. Thysanoptera 7 th.

4. Bagga, H. S. 1968. Fungi associated with cotton boll rot and their frequency. Plant Dis. Rep. 52(7):582-584.

5. Baird, R., and Carling, D. 1998. Survival of parasitic and saprophytic fungi on intact senescent cotton roots. J. Cotton Sci. 2:27-34.

6. Batson, W. E. 2001. Boll rots. Pages 36-38 in: Compendium of Cotton Diseases. T. L. Kirkpatrick and C. S. Rothrock, eds. American Phytopathological Society, St. Paul, MN.

7. Bell, A. A. 1967. Formation of gossypol in infected or chemically irritated tissues of Gossypium species. Phytopathology 57:759-764.

8. Bolkan, H. A., Dianese, J. C., and Cupertino, F. P. 1979. Survival and colonization potential of Fusarium moniliforme var. subglutinans in soil. Phytopathology 69:1298-1301.

9. Burke, J. J. 2002. Moisure sensitivity of cotton pollen; an emasculation tool for hybrid production. Agron. J. 94:883-888.

10. Edgerton, C. W. 1912. Flower infection with cotton boll rots. Phytopathology 2:23-27.

11. Farrar, J. J., and Davis, R. M. 1991. Relationships among ear morphology, western flower thrips, and Fusarium ear rot of corn. Phytopathology 81:661-666.

12. Fernando, W. G. D., Miller, J. D., Seaman, W. L., Seifert, K., and Paulitz, T. C. 2000. Daily and seasonal dynamics of airborne spores of Fusarium graminearum and other Fusarium species sampled over wheat plots. Can. J. Bot./Rev. Can. Bot. 78(4):497-505.

13. Funderburk, J., Stavisky, J., Tipping, C., Gorbet, D., Momol, T., and Berger, R. 2002. Infec-

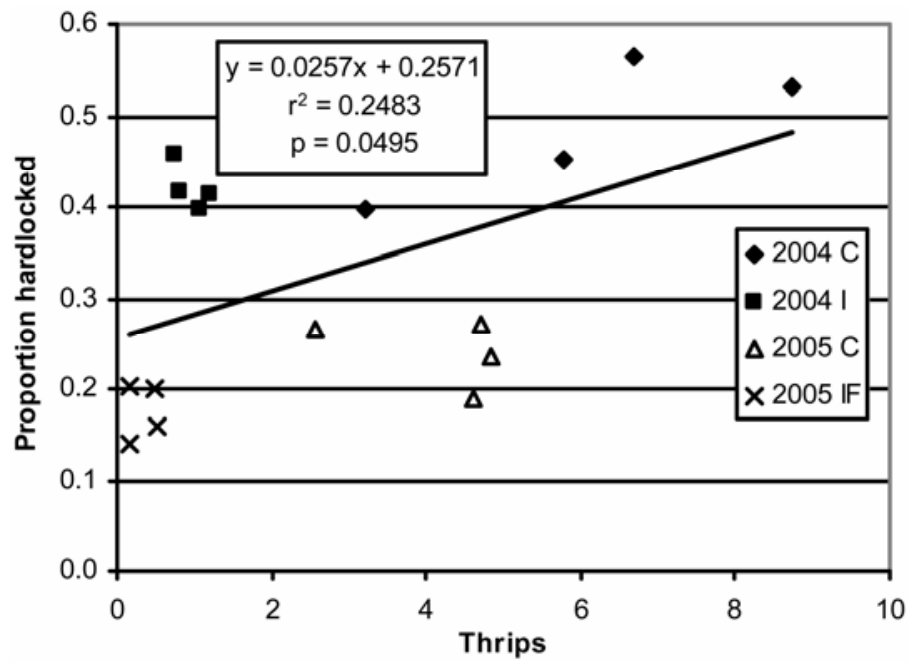

Fig. 6. Relationship between mean thrips numbers and hardlock incidence per plot in Quincy, FL for all treatments and years. Treatment $\mathrm{C}=$ untreated control, $\mathrm{I}=$ insecticide $(0.1 \mathrm{~kg} / \mathrm{ha}$ of spinosad on Mondays and $0.56 \mathrm{~kg} / \mathrm{ha}$ acephate $+0.04 \mathrm{~kg} / \mathrm{ha}$ lambda cyhalothrin on Thursdays), IF $=$ insecticide + fungicide $(0.1 \mathrm{~kg} / \mathrm{ha}$ of spinosad on Mondays, $0.56 \mathrm{~kg} / \mathrm{ha}$ acephate $+0.02 \mathrm{~kg} / \mathrm{ha}$ lambda cyhalothrin on Thursdays and $0.9 \mathrm{~kg} / \mathrm{ha}$ of thiophanate methyl every 2 weeks). tion of Frankliniella fusca (Thysanoptera: Thripidae) in peanut by the parasitic nematode Thripinema fuscum (Tylenchidae: Allantonematidae). Environ. Entomol. 31(3):558-563.

14. Mailhot, D. J., Marois, J. J., and Wright, D. L. 2007. Thrips on flowers of cotton. J. Cotton Sci. In press.

15. Marois, J. J., and Wright, D. L. 2004. Etiology, epidemiology, and control of Fusarium hardlock of cotton in the southeast: The possibilities. Pages 331-336 in: Proc. Beltwide Cotton Prod. Res. Conf.

16. Marois, J. J., Wright, D. L., Wiatrak, P. J., and Vargas, M. A. 2002. Association of Fusarium sp. with hardlock of cotton in the southeastern U.S. Proc. Beltwide Cotton Prod. Res. Conf.

17. Marois, J. J., Wright, D. L., and Wiatrak, P. J. 2005. Update of 2004 Fusarium hardlock research in Florida. Pages 152-156 in: Proc. Beltwide Cotton Prod. Res. Conf.

18. Ooka, J. J., and Kommedahl, T. 1977. Wind and rain dispersal of Fusarium moniliforme in corn fields. Phytopathology 67:1023-1026.

19. Palmateer, A. J., McLean, K. S., MorganJones, G., and van Santen, E. 2004. Frequency and diversity of fungi colonizing tissues of upland cotton. Mycopathologia 157:303-316.

20. Pickett, C. H., Wilson, L. T., and Gonzalez, D. 1988. Population dynamics and within-plant distribution of the western flower thrips (Thysanoptera: Thripidae), an early-season predator of spider mites infesting cotton. Environ. Entomol. 17(3):551-559.

21. Ramachandran, S., Funderburk, J., Stavisky, J., and Olson, S. 2001. Population abundance and movement of Frankliniella species and Orius insidiosus in field pepper. Agric. For. Entomol. 3:129-137.

22. Reitz, S. R., Yearby, E. L., Funderburk, J. E., Stavisky, J., Momol, M. T., and Olson, S. M. 2003. Integrated management tactics for Frankliniella thrips (Thysanoptera: Thripidae) in field-grown pepper. J. Econ. Entomol. 96:1201-1214.

23. Roberts, R. G., and Snow, J. P. 1984. Histopathology of cotton boll rot caused by Colletotrichum capsici. Phytopathology 74:390-397.

24. Roncadori, R. W. 1969. Fungal invasion of developing cotton bolls. Phytopathology 59:1356-1359.

25. Roncadori, R. W., McCarter, S. M., and Crawford, J. L. 1975. Evaluation of various control measures for cotton boll rot. Phytopathology 65:567-570.

26. Sanders, D. E., and Snow, J. P. 1978. Dispersal of airborne spores of boll-rotting fungi and the incidence of cotton boll rot. Phytopathology 68:1438-1441.

27. Seifert, K. A., Aoki, T., Baayen, R. P., Brayford, D., Burgess, L. W., Chulze, S., Gams, W., Geiser, D., de Gruyter, J., Leslie, J. F., Logrieco, A., Marasas, W. F. O., Nirenberg, H. I., O'Donnell, K., Rheeder, J., Samuels, G. J., Summerell, B. A., Thrane, U., and Waalwijk, C. 2003. The name Fusarium moniliforme should no longer be used. Mycol. Res. 107:643-644.

28. Sparnicht, R. H., and Roncadori, R. W. 1972. Fusarium boll rot of cotton: Pathogenicity and histopathology. Phytopathology 62:1381-1386.

29. Studebaker, G. E., and Kring, T. J. 2000. Letha and sublethal effects of early season insecticides on insidious flower bug (Orius insidiosus): An important predator in cotton. Pages 221-225 in: Proc. 2000 Cotton Research Meeting.

30. van de Wetering, F., Julshof, J., Posthuma, K., Harrewijn, P., Goldbach, R., and Peters, D. 1998. Distinct feeding behavior between sexes of Frankliniella occidentalis results in higher scar production and lower tospovirus transmission by females. Entomol. Exp. Appl. 88:9-15.

31. Wright, D. L., Marois, J. J., Wiatrak, P. J., and Katsvairo, T. 2004. History and overview of the hardlock problem in humid areas of the deep south. Proc. Beltwide Cotton Prod. Res. Conf. 